\title{
Mitigasi Resiko Investasi Bodong dan Aktualisasi Nalar Istiṣlāḥ
}

\author{
Firman Muhammad Arif \\ Institut Agama Islam Negeri Palopo (IAIN) Palopo \\ Balandai, Bara, Balandai, Palopo, Kota Palopo, Sulawesi Selatan 91914 \\ Email: firmanarif@iainpalopo.ac.id
}

\begin{tabular}{llll} 
Submit & $: 5$ Februari 2020 & Diterima & $:$ 13 Mei 2020 \\
Revisi & $: 11$ April 2020 & Terbit & $:$ 03 Juni 2020 \\
\hline
\end{tabular}

\begin{abstract}
Abstrak: Tulisan ini mengeksplorasi investasi yang sarat dengan manipulasi dan penggelapan. Realitas perkembangan investasi bodong dinilai tidak pernah mati bahkan jumlah korban dan kerugian dari tahun ke tahun semakin fantastis di beberapa wilayah. Kenyataan maraknya korban dan kerugian fantastis dalam delik investasi bodong tersebut dianalisa, dielaborasi dan dirumuskan dengan menggunakan perangkat nalar istiṣlāh sebagai nalar hukum klasik yang bersejalan dengan regulasi dan dinilai masih relevan dengan konteks kekinian. Jenis penelitian adalah penelitian kualitatif yang mendeskripsikan realitas di masyarakat atau diambil dari berbagai sumber yang minim dari manipulasi dan ilusi sehingga pengamatan yang dilakukan bersinergi dengan penginderaan atau dipercaya. Hasil penelitian menunjukkan bahwa upaya meminimalisir dampak maraknya investasi bodong diantisipasi dengan aktualisasi nalar istiṣlăh baik dengan cara normatif dan empiris. Corak penalaran istiṣlāhi dengan dua segmennya yaitu maṣlahah mursalah dan żarỉah dikolaborasikan dengan pendekatan hukum atau regulasi yang bersumber dari pemerintah untuk mendegradasi jumlah korban yang fantastis menjadi drastis. Edukasi literasi keuangan dan penindakan hukum perlu mendapat atensi utama.
\end{abstract}

Kata Kunci: investasi, realitas, aktualisasi, formalisasi, istiṣlāh

Abstract: This paper explores investments with manipulation and embezzlement. The reality of bulging investment development is considered to never die, even the number of victims and losses from year to year is increasingly fantastic in some areas. The fact of the rise in casualties and fantastic losses in the offense of the bulging investment is analyzed, elaborated and formulated using the istișlāh reasoning device as classical legal reasoning that is in line with regulations and is considered still relevant to the current context. This is qualitative research that describes reality in society or is taken from a variety of sources that are minimal from manipulation and illusion so that the observations made are synergized with sensing or trusted. The results showed that efforts to minimize the impact of the rampant bulging investment were anticipated by the actualization of reasoning in both normative and empirical ways. The style of istișlāhi reasoning with its two segments namely mașlahah mursalah and żarì ah is collaborated with a legal or regulatory approach sourced from the government to degrade the fantastic number of victims to be drastic. Financial literacy education and law enforcement need to get primary attention.

Keywords: investment, reality, actualization, formalization, istiṣlāḥ 


\section{Pendahuluan}

Islam menyajikan pedoman dan sumber yang relevan dari hingga sekarang bahkan masa mendatang. Keberlanjutan ajaran Islam tidak terbatas saat turunnya wahyu kepada Muhammad SAW dan umat yang hidup di masanya tetapi berlanjut hingga kini. Realisasi pencapaian kehidupan di dunia dan di akhirat adalah pencapaian kesejahteraan lahir dan batin. Salah satu cara mewujudkan kesejahteraan tersebut dengan berinvestasi sebagai pendongkrak sumber pendapatan di kemudian hari. ${ }^{1}$ Realisasi kesejahteraan pra atau pasca kematian dilakukan dengan kinerja investasi yang seirama dengan tuntunan agama dimana pelakunya akan dinilai sebagai orang yang cerdas spiritual, intelektual, sosial dan finansial. ${ }^{2}$

Pencapaian kehidupan yang lebih sejahtera di dunia tidak lepas dari adanya investasi dan kesiapan menghadapi berbagai kemungkinan, baik yang berpotensi menjanjikan atau memberikan nestapa yang tidak diharapkan. Pola memenuhi kebutuhan ekonomi ada yang dijalankan dengan sederhana karena memang tuntutan kebutuhan masyarakat belum beragam saat itu. Seiring dengan dinamika politik dan ekonomi, keagamaan umat manusia diamalkan dengan penuh keyakinan, tanpa atau minim dari rasionalitas personal - individual dari penganut agama. Keadaan tersebut dinamakan masyarakat tradisional yang artinya kehidupan berjalan dengan banyak berpedoman kepada sisi tradisional manusia. ${ }^{3}$

Penetrasi teknologi lebih cepat dibandingkan tradisi dan budaya dalam komunitas masyarakat. Contoh nyata dari beberapa permainan tradisional yang terkesan ditinggalkan karena pesona gawai lebih memikat padahal permainan klasik sarat dengan nilai kebersamaan dan interaksi sosial yang terbangun sejak dini. Dalam aktifitas ekonomi terdapat pola transaksi ekonomi klasik yang mulai terpinggirkan karena penetrasi teknologi yang dinilai masif, agresif dan nyaris tak terbendung.

Dalam beberapa hal, rasionalitas dalam ajaran agama cenderung dimarginalkan karena perkembangan mindset yang cenderung lebih memprioritaskan produk daripada proses, mengedepankan akselerasi dengan kecenderungan menghalalkan segala cara daripada menempuh cara yang halal. ${ }^{4}$ Modernisasi dalam semua bidang selalu diukur dengan logika dan materialistis sehingga suatu perbuatan atau kejadian tidak bisa diterima oleh akal manusia dan material interest (kepentingan materi).

Seseorang yang jauh dari hal tersebut dinilai belum mampu bangkit dari ketertinggalan. ${ }^{5}$ Investasi dalam ranah kehidupan lebih banyak berkaitan dengan penanaman uang atau modal dengan tujuan memperoleh keuntungan. Penawaran berbagai macam bisnis investasi di masa sekarang semakin merebak di kalangan masyarakat. Beberapa ada yang menawarkan investasi di ranah ternak, perkebunan jati, perdagangan mata uang, dan lain sebagainya. Perkembangan investasi tersebut menunjukkan bahwa bisnis investasi telah merambah di berbagai bidang usaha dan di antaranya menjanjikan atau terindikasi sarat dengan manipulasi, penggelapan dan pencucian uang. ${ }^{6}$

\footnotetext{
Mardhiyah Hayati, “Investasi Menurut Perspektif Ekonomi Islam,” Ikonomika: Jurnal Ekonomi Dan Bisnis Islam 1, no. 1 (2016). Abdul Aziz, Manajemen Investasi Syariah (Bandung: Alfa Beta, 2010), 14.

Asmawi, Dimensi-Dimensi Syari'ah Dari Teologi, Hukum, Akhlaq Sampai Sejarah Pemikiran (Tulungagung: IAIN Tulungagung Press, 2013), 69.

4 Abdul Hamid Barahimi, Al 'Adalah Al Ijtimaiyyah Wa Al Tanmiyah Fi Al Iqtisad Al Islamiy (Beirut: Dar al Fikr al Mu'asir, 1997 ), 54. Hayati, "Investasi Menurut Perspektif Ekonomi Islam," 67-8

6 Yudi Zulfahri, “Testimoni Mantan Anggota Jaringan Terorisme," in Dialog Pelibatan Civitas Academica Dalam Pencegahan Terorisme Melalui Forum Koordinasi Pencegahan Terorisme (FKPT) Sulawesi Selatan (Palopo: IAIN Palopo Press, 2019).
} 
Tulisan ini mengeksplorasi fenomena maraknya investasi dengan intrik penipuan, penggelapan, dan pencucian uang yang mengarah pada penghimpunan dana untuk aktifitas terorisme meskipun belum sepenuhnya terdeteksi namun tetap harus ditelaah dan diwaspadai. ${ }^{7}$ Kecermatan menjadi harga mati dalam menghadapi tawaran investasi dari oknum yang mungkin saja bersikap ramah saat penawaran namun berakhir dalam nelangsa yang tak berujung dan terpaksa bersikap tabah akibat tertipu, terjerembab dalam aksi culas dan curang dari oknum yang tidak bertanggung jawab. Kasus penipuan jamaah umrah yang dilakukan oleh First Travel, Abu Tour dan travel-travel lainnya adalah kasus sensasional yang menyalahi prosedur dalam etika ekonomi karena aktifitas finansialnya cenderung mendongkrak kekayaan pribadi.

Penawaran investasi yang bermuatan manipulasi dinilai berbahaya karena memanfaatkan gagal paham masyarakat untuk menipu dengan iming-iming imbal hasil yang tinggi dan tidak wajar. ${ }^{8}$ Perlindungan hukum kepada korban investasi bodong mutlak diperlukan karena pelaku investasi bodong wajib diproses secara hukum dan dipidana supaya keresahan tidak merebak karena adanya asumsi apriori pemerintah dalam melindungi warganya dan terkesan memperkuat ketidakpastian hukum. ${ }^{9}$

Realitas tersebut tentu membuat miris sehingga diperlukan analisa dan solusi komprehensif dalam hukum Islam supaya korban yang jumlahnya fantastis menjadi drastis, dari maksimal menjadi minimal. Realitas ketimpangan yang marak terjadi dalam bentuk investasi bodong dinilai mengkerdilkan nilai-nilai Islam yang universal dan sebagai umat Islam dengan jumlah mayoritas perlu diberikan pemahaman mengenai investasi yang kemudian diaktualisasikan dalam bentuk praktik atau perilaku dalam berinvestasi sehingga aksi manipulasi dari oknum bisa diminimalisir.

\section{Realitas Perkembangan Investasi}

Investasi kadang bersejalan dengan kenyataan atau kadang tidak bersejalan dengan realitas. Ruang lingkup investasi ada yang berskala makro atau mikro, bersinggungan dengan kehidupan individu atau kehidupan kolektif, baik dalam bentuk wilayah, komunitas atau pemerintahan. Investasi dalam realitas kehidupan selalu terkait dengan keuangan dan ekonomi. Investasi ialah kinerja akal dan fisik yang berkenaan dengan sesuatu di masa sekarang untuk mendapatkan manfaat yang lebih banyak di masa mendatang. Pemaknaan lainnya adalah aktifitas dengan menempatkan dana pada periode tertentu dengan harapan penggunaan dana tersebut bisa didayagunakan untuk masa depan. ${ }^{10}$

Negara dan pihak swasta hadir di tengah masyarakat dengan menyiapkan program investasi seperti tabungan pendidikan, tabungan untuk penyelenggaraan ibadah haji atau umrah, jaminan kesehatan yang baik dengan asuransi kesehatan, jaminan finansial keluarga pasca meninggal dengan asuransi jiwa, investasi perumahan, usaha, saham, dan penanaman modal yang secara umum berorientasi pada kesiapan menghadapi kemudian hari dan mendongkrak nilai pendapatan.

Investasi yang berkenaan dengan pemerintahan atau dalam tata kelola wilayah adalah

\footnotetext{
Hamli, "Kebijakan Dan Strategi Pencegahan Terorisme Bersama Perguruan Tinggi Sebagai Direktur Pencegahan BNPT," in Dialog Pelibatan Civitas Academica Dalam Pencegahan Terorisme Melalui Forum Koordinasi Pencegahan Terorisme (FKPT) Sulawesi Selatan (Palopo: IAIN Palopo, 2019).

8 Hotman Paris. \& Ajeng Kamaratih Hutapea, “Investasi Bodong Dan Perlindungan Perempuan,” Metro TV (Indonesia, 2019).

Tongam Lumban Tobing, "Perang Melawan Investasi Ilegal,” Edukasi Konsumen (Jakarta, 2017).

10 Latif Rizqan, "Investasi Dalam Islam Dan Penerapannya," Kompasiana, 2019, kompasiana.com.
} 
indikator pertumbuhan dan berkembangnya ekonomi dalam suatu area. Investasi berkaitan erat dengan kesempatan kerja, gambaran aktifitas ekonomi dan penilaian sebuah proses produksi. Dalam mewujudkan pembangunan nasional, pemerintah masih belum mampu mendanai seutuhnya kebutuhan pembiayaan yang diperlukan sehingga beberapa model investasi dikembangkan oleh pihak swasta untuk mengakomodir pihak lainnya. ${ }^{11}$

Perkembangan investasi dengan variannya di masa sekarang tidak bisa disejajarkan atau disamakan karena ada varian investasi konstruktif atau destruktif, usaha didominasi dengan sesuatu yang sarat dengan manipulasi atau modifikasi, dampaknya bisa kreatif atau reaktif. Investasi yang berkenaan dengan pemerintahan biasanya bersinggungan dengan politik dan eksistensi politik sarat dengan kepentingan atau kemanusiaan. Jika investasi sarat dengan nilai kemanusiaan maka progresnya akan transparan dan komprehensif namun jika investasi didominasi dengan kepentingan maka kinerjanya terkesan nakal dan sarat dengan manipulasi, pencucian dan penggelapan karena progresnya yang tidak berjalan.

Dalam paradigma Islam, investasi tidak sama dengan yang dilakukan oleh banyak pihak. Investasi dalam Islam bermuatan prinsip bagi hasil, halal dan memiliki manfaat, bukan hanya berguna dalam kehidupan tapi juga setelah kematian. ${ }^{12}$ Investasi yang dianjurkan dalam Islam adalah investasi yang secara eksplisit tertuang dalam ajaran Alquran dengan berbagai ayatnya seperti QS. al Hasyr: 18, QS. Lukman: 34, QS. al-Baqarah: 261, QS. al-Nisa: 9.

Islam tidak melegalkan semua investasi kecuali yang bersejalan dengan teks, makna dan spirit Al-Qur'an saja yang boleh diikuti. ${ }^{13}$ Dalam ketatanegaraan atau figh daulah, keberadaan investasi ikut andil dalam mendongkrak perekonomian negara. Dalam ekonomi makro, investasi berperan menambah pendapatan nasional sehingga jika investasi mengalami kenaikan maka Produk Domestik Bruto atau Gross Domestic Product (GDP) akan ikut naik begitupun sebaliknya. ${ }^{14}$

Investasi menjelma sebagai senjata andalan untuk mendukung pertumbuhan ekonomi dan adanya pembiayaan dari investor memungkinkan perkembangan di berbagai bidang khususnya infrastruktur. ${ }^{15}$ Demikian pula dengan investasi secara mikro, beberapa investor memulai investasinya dari angka kecil atau besar. Bagi pemula, perhatian terhadap resiko investasi menjadi keharusan, kehati-hatian menjadi prinsip dan realisasi keuntungan menjadi asa yang diinginkan atau nihilnya penyesalan di kemudian hari. ${ }^{16}$

Secara mikro, tujuan investasi dapat dilihat dari kepentingan investor, baik secara langsung atau tidak langsung. Tujuan investor dalam melakukan investasi didasarkan dengan pertimbangan dan orientasi yang bersifat ekonomis, seperti kesempatan berusaha untuk mencapai keuntungan, menanamkan modal dengan harapan mendapatkan nilai tambah yang lebih besar dari modal yang ditanamkan, berusaha menjaga sekaligus menghindari dari kerugian yang disebabkan oleh merosotnya nilai mata uang. ${ }^{17}$

\footnotetext{
11 Ana \& Suratman Rokhmatussa'dyah, Hukum Investasi \& Pasar Modal (Jakarta: Sinar Grafika, 2011), 8.

12 Rizqan, "Investasi Dalam Islam Dan Penerapannya."

13 Sakinah, "Investasi Dalam Islam," Iqtishadia 1, no. 2 (2014).

14 Eddy Cahyono Sugiarto, "Investasi Dan Indonesia Maju," Kementerian Sekretariat Negara Republik Indonesia, 2019, setneg. go.id.

15 Sri Mulyani Indrawati, “Perkembangan Investasi Di Indonesia Tahun 2019," Sahabat Pegadaian, 2018, sahabatpegadaian.com.

16 Fahmi Arya, "Investasi Mikro Solusi Investasi Untuk Pemula," CNBC Indonesia, 2019, cnbcindonesia.tv.

17 Muhammad. \& Muhammad Suryani H. Kastulani, "Pengaruh Investasi Dalam Pengembangan Masyarakat Lokal," Kutubkhanah 3, no. 2 (2019).
} 
Penanaman modal dalam tata kelola negara bisa dilakukan oleh investor lokal atau asing. Penanaman modal pertama kali dilakukan di Indonesia melalui kebijakan pemerintah kolonial Belanda yang memperkenankan masuknya modal asing Eropa untuk menanamkan usahanya di bidang perkebunan pada tahun 1870. Penanaman modal tersebut memungkinkan dilakukan di beberapa daerah jajahan. Pembukaan beberapa lahan pertanian menuntut adanya regulasi yang menopang kebijakan politik, peluang dan permintaan pasar yang meningkat.

Proklamasi kemerdekaan 17 Agustus 1945 secara yuridis menunjukkan babak baru dalam mengelola secara mandiri perekonomian untuk melaksanakan pembangunan nasional meskipun dalam kondisi tertatih-tatih ${ }^{18}$ karena kegaduhan politik yang tidak menentu seperti ramainya pemberontakan, kesemrawutan keamanan akibat kesenjangan sosial, ketimpangan pembangunan dan aksi masif tentara kolonial yang cenderung masih ingin eksis di wilayah jajahan. ${ }^{19}$ Payung hukum untuk penanaman modal asing dirintis sejak Kabinet Ali Sastroamdjojo I (1952-1953) supaya tidak mengganggu atau menghambat pembangunan masyarakat Indonesia. ${ }^{20}$

Negara manapun termasuk Indonesia membutuhkan investasi dari luar untuk membuka lapangan kerja meskipun adakalanya terlontar kata negatif bahwa investasi asing tidak lebih adalah penguasaan aset negara oleh asing. Ramainya investasi asing terlihat jelas dalam pemerintahan Orde Baru yang melakukan upaya stabilisasi setelah terjadinya gejolak ekonomi di masa Soekarno. ${ }^{21}$ Dalam catatan USAID September 1972, bahwa dalam periode 1967 hingga 1971 pemerintah Indonesia telah membuka pintu untuk 428 investor asing dengan total nilai investasi mencapai 1,6 miliar dollar di luar sektor minyak bumi. ${ }^{22}$

Keberlangsungan liberalisasi sangat kontras dari 1983 hingga 1997 dalam sektor industri, pangan dan pertanian seperti produksi pupuk kimia dan pestisida. ${ }^{23}$ Kekuasaan rezim Orde Baru yang fantastis diraih dengan mendongkrak legitimasi kekuasaan melalui berbagai cara seperti memasifkan propaganda pembangunan dengan segala kebijakan yang diarahkan pemerintah, baik secara represif atau persuasif. ${ }^{24}$ Masa Orde Baru, pembangunan ekonomi mengalami pertumbuhan 18 kali lipat pada pendapatan per kapita rata-rata sekitar 4,1 persen per tahun selama 1970-1996. ${ }^{25}$

Prestasi pembangunan tersebut ternyata tidak menunjukkan struktur perekonomian yang sesungguhnya karena selama 32 tahun lebih banyak menitikberatkan peningkatan pertumbuhan ekonomi semata dan tidak bersinergi dengan peningkatan kualitas pembangunan manusia secara utuh dan tidak diiringi dengan penguatan berbagai institusi baik publik atau swasta yang memiliki peran penting dalam akselerasi sistem ekonomi yang baik. Sebagai akibatnya, krisis moneter yang menginfeksi perekonomian tahun 1997 merebak menjadi krisis multidimensi yang meliputi ekonomi, politik, sosial, dan bahkan hukum.

Krisis multidimensi yang mengepung ekonomi Indonesia dan melanda perekonomian Asia

\footnotetext{
18 Abdul Hakim, "Perbandingan Perekonomian Dari Masa Soekarno Hingga Susilo Bambang Yudhoyono 1945-2009," Ekonomika Bisnis 3, no. 2 (2012).

19 Batara Mulia Hasibuan, “Investasi Dan Sejarah Perkembangan Investasi Asing Di Indonesia," BINUS, 2019, business-law.binus. ac.id.

20 Hasibuan.

21 Danang Sugiyanto, “Investasi Asing Mengalir Ke RI Sejak Era Orde Baru,” Detik, 2018, finance.detik.com.

22 Kuntowijoyo, Pengantar Ilmu Sejarah (Yogyakarta: Bentang Budaya, 1995), 35.

23 Zainal Ibnu Nurdin, "Peran Investasi Asing Dalam Perekonomian Indonesia Tahun 1967-1998," repository.upi.edu, 2019.

24 Dwi Cahyono. \& Gayung Kasuma Hadi, “Propaganda Orde Baru 1966-1980,” Verleden 1, no. 1 (2012).

25 Awan Wibowo Laksono Poesoro, "Membangkitkan Investasi Di Indonesia," 2019, theindonesiainstitute.com.
} 
Timur dan Tenggara pada pertengahan 1997 maka Indonesia belum sepenuhnya sembuh dari permasalahan ekonomi, moneter, politik, hukum dan sosial. Tiga pemerintahan pasca rezim Orde Baru yaitu BJ Habibie, Abdurrahman Wahid dan Megawati belum sepenuhnya melakukan perbaikanperbaikan yang signifikan terhadap berbagai permasalahan yang ada. Pemulihan ekonomi secara menyeluruh hingga kini terus dilakukan dengan perbaikan-perbaikan yang optimal yang berkenaan dengan ekonomi makro dan mikro. ${ }^{26}$

Adapun investasi berskala mikro lebih banyak menyentuh area individual atau komunitas tertentu dimana penggunaan dana pribadi dimanfaatkan untuk mendapatkan keuntungan finansial atau dengan praktisnya disebut penggunaan uang untuk mendapatkan uang. Pengambilan keputusan dalam ekonomi mikro ditempuh dengan sesuatu yang paling rasional dan berorientasi meningkatkan profitabilitas dan pertumbuhan. Pengambilan keputusan dalam ekonomi makro lebih berorientasi kestabilan dan keseimbangan. ${ }^{27}$ Realitas perkembangan investasi, baik makro atau mikro (konsumen, industri atau rumah tangga) menghadirkan berbagai program yang dapat dinikmati oleh kalangan masyarakat. ${ }^{28}$

Berpikir realistis dalam tujuan berinvestasi adalah investasi yang sepatutnya memperhatikan keadaan finansial yang terjadi saat itu. Perkembangan investasi dalam kenyataannya seperti asuransi, perencanaan perumahan, perencanaan pensiun atau penyediaan dana darurat ialah model investasi dana yang harus dilewati dan mengharuskan adanya modifikasi karena kondisi ekonomi yang bersifat fleksibel dan berubah-ubah. Beberapa pihak dengan pikiran tradisional selalu mengharapkan return (pengembalian) secara tunai dan bukan berupa manfaat. Hal tersebut biasanya dalam bentuk asuransi murni yang hanya memberikan pertanggungjawaban bilamana nasabahnya mengalami sakit atau musibah. Padahal jika seseorang sakit, bisa jadi uang pembayaran rumah sakit jauh lebih besar dibandingkan dengan premi bulanan yang dibayarkan. ${ }^{29}$

Untuk memberi jaminan keamanan di masa depan, maka banyak masyarakat mengincar berbagai produk keuangan. Asuransi dan investasi adalah produk keuangan yang diminati dan dinilai ideal sebagai produk yang mesti dimiliki hingga kini. Fungsi dari asuransi adalah perlindungan terhadap seseorang atau keluarganya dalam hal finansial dari resiko yang datangnya secara tiba-tiba dan mendadak atau tidak terduga. Fungsi dari investasi adalah memenuhi kebutuhan di masa depan agar daya beli yang dimiliki oleh seseorang tidak habis terkuras oleh inflasi. Kedua produk tersebut semuanya bernilai penting. ${ }^{30}$

Investasi secara umum mengkampanyekan ekspektasi keuntungan sehingga pengetahuan tentang investasi mutlak diperlukan. Investasi bodong atau yang menjanjikan keuntungan besar namun mengarah ke penipuan masih marak di Indonesia. Penetrasi teknologi digital telah merambah di bidang investasi seperti simpanan di koperasi, multi level marketing, arisan online hingga simpanan di bank digital. Keberadaan investasi bodong yang masih marak dalam setiap tahunnya didasarkan iming-imingi cara mudah menjadi orang kaya atau pengembalian dana dengan jumlah besar dan waktu pengembalian yang relatif singkat sehingga banyak orang berakal yang tergerus dengan aksi yang sarat dengan intrik manipulatif. ${ }^{31}$

\footnotetext{
26 Poesoro.

27 Fahmi Arya, Investasi Mikro Solusi Investasi untuk Pemula, www.cnbcindonesia.tv tanggal 31 Maret 2019.

28 Arya, "Investasi Mikro Solusi Investasi Untuk Pemula."

29 Paulus Yoga, “Asuransi Kesehatan, Tabungan Atau Investasi," Infobanknews, 2017, infobanknews.com.

30 Wimboh \& Tongan Lumban Tobing Santoso, "Fintech Ilegal Dan Investasi Bodong," in Kuliah Umum Bersama Otoritas Jasa Keuangan \& Satgas Waspada Investasi (Jember: Fakultas Ekonomi dan Bisnis Universitas Jember, 2019).

31 Ferdinandus Setu, "Fintech Ilegal Tidak Pernah Mati," Berita Satu TV (Jakarta, 2019).
} 
Salah satu dari investasi bodong seperti kasus Me Miles di awal 2020 yang menjurus ke penipuan, tidak berizin atau menyalahi perizinan serta skema piramida yang digunakan yang serupa dengan money game karena bonus yang diberikan bukan berdasarkan jumlah barang yang dijual dan nyatanya tidak ada barang yang dijual. Wilayah Indonesia dengan 34 propinsi, 416 kabupaten, 98 kota dan 74.954 desa $^{32}$ dinilai cukup rumit dan kompleks sehingga butuh penanganan menyeluruh yang memerlukan skill, multi kompetensi, kolaborasi dan kebersamaan apik dari jajaran top down dan buttom up dalam menata dan mengelola wilayah, struktur sosial dan politik. Keberadaan investasi bodong diibaratkan sebagai bom waktu yang sewaktu-waktu akan membuat gaduh dan meresahkan sehingga butuh solusi yang sifatnya preventif dan kuratif.

\section{Aktualisasi Nalar Istiṣlāh}

Islam tidak akrab dengan stagnasi dalam perkara muamalah namun masif menuntun umatnya supaya tidak terpedaya dan tidak terjebak dalam kehidupan dunia yang memukau. Hubungam antara teori hukum dan perubahan masyarakat di era globalisasi adalah persoalan esensial dalam filsafat hukum. Islam menyatakan hukumnya șalihun likulli zamānin wa makānin (hukum yang cocok di setiap zaman dan waktu). Keberadaan fikih Islam mencerminkan teori kewajiban dan teori etika bahkan karakternya fleksibel, dinamis, menerima perubahan, dan beradaptasi dengan problematika perubahan zaman..$^{33}$

Seorang manusia dalam melaksanakan kewajibannya atau menjauhi larangannya dengan dasar agama, tidak tetap dalam kondisi tertentu sehingga penerapan hukumnya juga akan berbeda. Perubahan bisa terjadi karena perubahan yang disebabkan oleh berbagai kejadian alam dan bisa terjadi karena usaha manusia sendiri. Adapun bentuk perubahan disimpulkan Ibnu Qayyim dengan ungkapannya:

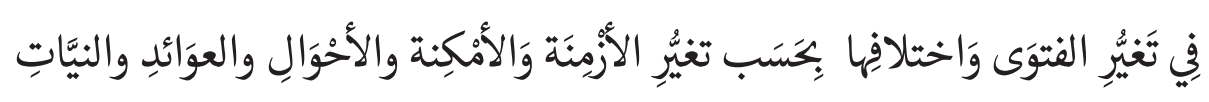

Fatwa berubah dan berbeda sesuai dengan perubahan waktu, tempat, keadaan, adat kebiasaan dan niat. ${ }^{34}$

Berbagai macam persoalan yang bermunculan dalam masa modern diramaikan oleh berbagai perkara yang belum diakomodir dan dibahas secara tekstual dan maknanya dalam Al-Qur'an dan Hadis Nabi seperti penetrasi investasi di bidang teknologi perlu direspon dan ditangani secara kompleks. ${ }^{35}$ Pernyataan tersebut bernilai benar dan pada hakikatnya yang berubah adalah keadaan atau kondisi manusia atau alam yang disebabkan oleh manusia itu sendiri sehingga perubahan apapun bentuknya dimaksudkan dengan memudahkan, efisiensi atau efektifitas waktu dan bukan dengan maksud memudah-mudahkan dan menghalalkan segala cara atau menerobos tanpa pertimbangan syar'i ${ }^{36}$

Persoalan tersebut adalah perkara kontemporer sebagai imbas dari kemajuan ilmu pengetahuan dan teknologi yang tentunya ajaran Islam patut dan pantas diberlakukan sepanjang zaman dengan

\footnotetext{
32 Editorial, “Pembangunan Daerah Tertinggal Dan Transmigrasi Republik Indonesia," Kementerian Desa, 2019, kemendesa.go.id

33 Nur Kholis, "Antisipasi Hukum Islam Dalam Menjawab Problematika Kontemporer: Kajian Terhadap Pemikiran Maslahah Mursalah Al Ghazali," Al Mawarid 1, no. 1 (2010).

34 Ibnu Qayyim, I'lam al Muwaqqi' in 'an Rabbi al Alamin (Beirut: Dar al Jail, tt.), Juz III, h. 3

35 Nadirsyah Hosen, "Menggagas Ijtihad Kontemporer Di Bumi Nusantara," in Milad Ke-50 IAIN Tulungagung (IAIN Tulungagung: IAIN Tulungagung Press, 2018).

36 Bhima Yudistira Adhinegara, “Tren Milenial Dan Industri 4.0” (Yogyakarta, 2019).
} 
menyajikan solusi syar'i atau jalan keluar yang bersinergi dengan teks, konteks dan spirit keislaman. ${ }^{37}$ Adapun solusi yang diperkenankan dan dianggap pantas dalam menyikapi problematika kehidupan umat adalah dengan menempuh cara ijtihad. ${ }^{38}$ Penetrasi ijtihad tersebut melahirkan produk hukum yang disebut dengan fikih yang dalam realitasnya merealisasikan sumber hukum Islam yang merupakan furu' (cabang) dari ashli-nya (sumbernya). ${ }^{39}$

Penghimpunan dana yang menjadi kebiasaan dalam masyarakat modern merupakan kegiatan keuangan yang dilakukan dalam bentuk simpanan dan menyalurkannya ke masyarakat dalam bentuk kredit atau dalam bentuk-bentuk lain dengan tujuan meningkatkan taraf hidup orang banyak dan mendongkrak kesejahteraannya di masa mendatang. Investasi dilakukan sebuah badan usaha yang sah atau badan hukum baik dari pemerintah dan non pemerintah untuk mengakomodir dan melayani masyarakat. ${ }^{40}$

Investasi bertujuan memperoleh kebebasan keuangan di masa depan namun dengan menjamurnya investasi yang tidak mengantongi izin otoritas atau mengantongi izin namun dalam operasionalnya menyalahi regulasi dan undang-undang alias bodong dipastikan akan menimbulkan keresahan di tengah masyarakat.

Jika fintech ilegal diibaratkan dengan rentenir online maka investasi bodong dianalogikan dengan kegiatan yang sarat dengan intrik dan manipulasi terselubung namun mampu menggiring seseorang silau dengan money game yang hanya fokus merealisasikan keuntungan sepihak dan memanfaatkan kedunguan perihal literasi keuangan dari masyarakat. ${ }^{41}$ Kegiatan tanpa izin usaha atau menyalahi prosedur hukum berpotensi menimbulkan kerugian fantastis yang bukan hanya terkait dengan finansial tapi juga menggerus arti sebuah kepercayaan secara bertahap, menstimulus potensi konflik, menggiring aksi kekerasan, bahkan memparipurnakan kekecewaan secara permanen yang ujungnya berakibat pada depresi akut sehingga menghantui korbannya yang terjebak dalam investasi bodong tersebut. ${ }^{42}$

Keberadaan fintech ilegal yang semakin menjamur telah memicu dan menyulut semangat Satgas Waspada Investasi OJK mengoptimalkan perannya dengan mengatur, mengawasi dan melindungi masyarakat. Kegesitan Satgas Waspada Investasi OJK RI menemukan setidaknya 144 entitas yang menjalankan kegiatan usaha peer to peer lending ilegal alias tidak terdaftar dan tidak berizin dari Otoritas Jasa Keuangan. Ketua Satgas Waspada Investasi, Tongam L. Tobing mengungkapkan bahwa sampai April 2019, ditemukan 543 fintech ilegal baru, di mana pada tahun 2018 ditemukan 404 fintech ilegal. ${ }^{43}$

Dengan begitu, terhitung April 2019 sudah ada sejumlah 947 fintech ilegal yang ditangani oleh Satgas Waspada Investasi. ${ }^{44}$ Dalam pernyataan yang dipublikasikan Berita Satu Juli 2019, telah terendus 1087 fintech ilegal mengintai masyarakat dan hanya 100 yang terdaftar di OJK. Laporan tersebut didapatkan setiap bulannya dari Otoritas Jasa Keuangan dan Kominfo yang saling bahu

\footnotetext{
37 Ahmad Musyahid. Idrus, "Tradisi Penalaran Filosofis Dalam Hukum Islam," Al Daulah 3, no. 1 (2014).

38 Fathurahman, "Pengembangan Metode Ijtihad Kontemporer," Diskursus Islam 2, no. 2 (2014).

39 Firman Muhammad Arif, "Pengembangan Metode Ijtihad Istislahi Dalam Maqasid Al Syari'ah," Ahkam: Kajian Ilmu Hukum Dan Syariah 4, no. 1 (2014).

40 Muhammad Zaki, “Aplikasi Maqasid Al Syari'ah Pada Sistem Keuangan Syariah,” BISNIS 3, no. 2 (2015).

41 Santoso, "Fintech Ilegal Dan Investasi Bodong."

${ }^{42}$ Hutapea, "Investasi Bodong Dan Perlindungan Perempuan."

43 Santoso, "Fintech Ilegal Dan Investasi Bodong."

44 Tobing, "Perang Melawan Investasi Ilegal."
} 
membahu memblokir fintech ilegal dan memberhentikan aksi investasi bodong. ${ }^{45}$

Adapun investasi bodong atau kegiatan usaha tanpa izin dari otoritas yang berwenang dan berpotensi merugikan masyarakat seperti yang dikutip dalam keterangan resmi Satgas Waspada Investasi OJK terhitung 7 Oktober 2019 sebanyak 27 dengan rincian: 11 trading forex tanpa izin, 8 investasi cryptocurrency tanpa izin, 2 multi level marketing tanpa izin, 1 travel umrah tanpa izin, dan 5 investasi lainnya. ${ }^{46}$ Menjalankan bisnis investasi dengan sistem money games dengan mekanisme piramida sebagaimana yang dilakukan PT Amoeba International dengan PT Q-Net sebagai induk perusahaan yang menjalankan perdagangan sistem piramida hanyalah contoh kasus yang viral dari sekian banyak kasus investasi yang meresahkan masyarakat.

Kasus Q-Net mewakili kasus investasi bodong lainnya dan beberapa korbannya tidak sadar dan masih berkeyakinan bisa sukses atau merasa tidak ditipu oleh ajakan oknum dengan bisnis piramida. Dugaan kuat telah terjadi cuci otak karena beberapa korban ada yang menjual sapi bahkan berhutang ke rentenir hingga menggadaikan aset berharga ${ }^{47}$ Contoh kasus tersebut membuktikan bahwa dari sejumlah bukti yang dilakukan pelaku investasi bodong terungkap adanya permainan uang (money game), sistem piramida, dan skema ponzi yang menjadi momok dalam investasi bodong.

Kedudukan Islam sebagai ajaran yang paripurna dengan karakternya yaitu syumūliyyah (universal) dan kämilah (kesempurnaan) menyajikan solusi komprehensifatas permasalahan yang dihadapi umat yang sesuai dengan kehendak syar'i. ${ }^{48}$ Tradisi keilmuan yang terdapat dalam hukum Islam menyikapi secara terbuka perihal perkembangan zaman dan sosiologi masyarakat. Keberadaan ahlual-ra'yi (pakar dalam rasional dan logika hukum) dan ahlu al-ḥadiṣ (pakar dalambidang teks hukum) dikolaborasikan untuk memberikan jalan keluar dari berbagai problematika dalam masyarakat. ${ }^{49}$

Sumber tasyri ketiga yaitu ijtihad atau fikih menyajikan corak penalaran ta'lili (berwujud metode qiyas dan istih̆sān) ${ }^{50}$ dan corak penalaran istișlāhi (maslahah mursalah dan nalar żarīah). ${ }^{51}$ Kedua penalaran filosofis tersebut yang terdapat dalam hukum Islam menyikapi dan merespon maraknya investasi bodong dengan menyajikan corak yang khas yaitu menangkap nilai-nilai mafsadah (kerusakan) yang terkandung dalam nash dengan mempertimbangkan realitas sosial yang berkembang dalam masyarakat.

Corak penalaran ta'lili (qiyas dan istihsān) mendominasi penjelasan teks dan makna nas dengan memparipurnakan suatu ketetapan hukum berbasis maksud syar'i yang memiliki ilat (motif) tertentu sebagai sesuatu yang menjadi sebab atau yang melatarbelakanginya..$^{52}$ Berbeda halnya dengan corak penalaran isitișlahi yang memparipurnakan suatu hukum dalam menyikapi masalah yang tidak diakomodir oleh nas dan delegitimasi ijma' (konsensus ulama) berbasis purifikasimaslahat atau maslahat yang tidak diterangkan namun tidak dibatalkan oleh syariat..$^{53}$

\footnotetext{
45 Setu, "Fintech Ilegal Tidak Pernah Mati."

46 Tongam Lumban Tobing, “Jangan Tertipu, Ini Daftar Invstasi Bodong Yang Ditutup OJK," CNBC Indonesia, 2019, cnbcindonesia. com.

47 Abdul Jalil, “Sepak Terjang Bos Q-Net Asal Madiun Terhenti Di Lumajang," Suara Bisnis, 2019.

48 Fawzi Usman Salih, Al Qawa'id Wa Al Dawabit Al Fiqhiyyah Wa Tatbiqatuha Fi Al Siyasah Al Syar'iyyah (Riyadh: Dar al 'Asimah, 2011), 51.

49 Idrus, "Tradisi Penalaran Filosofis Dalam Hukum Islam."

50 Muhammad Mustafa Syalabi, Ta'lil Al Ahkam (Beirut: Dar al Nahdah al 'Arabiyyah, 1981), 14-5.

51 Dedi Ismatullah, Sejarah Sosial Hukum Islam (Bandung: Pusataka Setia, 2011), 35.

52 Abdul Wahab Khallaf, Masadir Al Tayri' Al Islamiy Ma La Nas Fih (Kuwait: Dar al Qalam li Nasyri wa al Tawzi', 1992$), 49$.

53 Khallaf, 124.
} 
Berdasarkan pernyataan tersebut maka investasi dengan skema multi level marketing, ponzi, piramida dan money game adalah skema investasi yang tidak diakomodir nas dan memperkuat kepastian delegitimasi ijma' namun harus tetap direspon dengan penjelasan yang bertumpu pada maslahat sehingga dikategorikan dengan maslahah mursalah. ${ }^{54}$ Adapun penetrasi nalar żarïah dalam kegiatan investasi bodong tidak lain untuk dirumuskan dan dipatenkan dalam bentuk opsi antara dilanjutkan atau dihentikan (fathu atau sadd al żarỉah). Corak penalaran istị̂lāh didayagunakan dengan penetrasi nalar żarỉah namun dengan menitikberatkan ketatnya persyaratan. Beberapa syarat yang harus diintegrasikan adalah sebagai berikut:

1. Syarat pertama adalah ketetapan mengenai investasi tertentu dievaluasi dengan penyelidikan, analisa dan penelitian sehingga substansi yang terdapat dalam investasi bodong memang terbukti sarat dengan mafsadah daripada maslahatnya atau mafsadahnya optimal dan maslahatnya nihil sama sekali..$^{55}$ Konten maslahat dalam investasi tersebut dinilai paradoks dengan maslahat yang dikehendaki syariat. Maslahat tersebut dinilai hanya bertumpu pada hawa nafsu bahkan menghalalkan segala cara dalam merealisasikan maslahat. Dengan demikian maka maslahat tersebut adalah batil (maslahat mulghat) dan karenanya tidak pantas dilanjutkan dan secepatnya dihentikan. Pernyataan tersebut bersejalan dalam ajaran Islam tentang menjalani hal yang tidak berbahaya dan membahayakan. ${ }^{56}$ Maslahat mulghat atau maslahat yang tertolak dalam spirit nas dan ijma' dinilai hanya sebagai upaya melakukan pembenaran dan tidak mengungkapkan kebenaran, menghalalkan segala cara dan tidak menempuh cara yang halal, dan didominasi dengan berbagai intrik yang memanipulasi. ${ }^{57}$ Maslahat didalamnya lebih bersifat ilusi (anganangan) dan dipengaruhi oleh hawa nafsu sehingga tidak boleh memakai maslahat ilusi tersebut sebab masih maslahat hakiki.

2. Adapun syarat kedua adalah maslahat dalam menilai sebuah investasi tersebut adalah maslahat hakiki dan bersifat umum. Maslahat dengan profit yang hanya bertumpu pada sebagian orang atau individu tertentu namun menghiraukan nasib masyarakat umum sehingga jenis maslahat tersebut tidak pantas dijadikan sebagai landasan. Begitupun dengan penggunaan skema piramida, ponzi dan money game adalah skema investasi yang maslahatatau profitnya dimanfaatkan secara optimal pada jaringan tingkat atas dan jaringan tingkat yang paling bawah menjadi penyuplai untuk kepentingan diatasnya. Ketika peserta tingkat bawah tidak lagi mendapatkan peserta baru dibawahnya dalam investasi tersebut maka yang tersisa adalah kegaduhan dan kerugian yang jumlahnya fantastis.

Kendala yang selama ini menjamur di masyarakat adalah disfungsi atau minimnya akal sehat dalam memahami risk and reward yaitu pertimbangan optimal mengenai resiko dan keuntungan sehingga lebih banyak yang dipertimbangkan adalah reward (keuntungan) dan minim dalam mempertimbangkan risk (resiko). Realitas yang terjadi di masyarakat membuktikan bahwa maraknya korban dalam investasi bodong karena iming-iming pengembalian dalam jumlah yang besar dan dilalui dalam waktu yang relatif singkat. Demikian pula dengan minimnya optimalisasi 2-L yaitu logically and legalistic (secara logis

\footnotetext{
54 Hosen, "Menggagas Ijtihad Kontemporer Di Bumi Nusantara."

55 Abu al Walid Muhammad bin Rusyd al Hafid, Al Daruriy Fi Usul Al Figh Aw Mukhtasar Al Mustasfa (Beirut: Dar al Garb al Islamiy, 1994), 137.

56 A Djazuli, Kaidah-Kaidah Fikih, Kaidah-Kaidah Hukum Islam Dalam Menyelesaikan Masalah-Masalah Yang Praktis (Jakarta: Kencana Prenada Media, 2010), 6.

57 Yusuf Dutton, Asal Mula Hukum Islam, Al Qur'an, Muwatta Dan Praktik Madinah (Jakarta: Islamika, 2013), 25.
} 
dan memenuhi hukum) sehingga investasi bodong seakan tidak pernah berhenti dan selalu muncul dengan wajah dan penampilan yang baru dan memukau calon korban berikutnya. Ketegasan mendayagunakan 2-L yaitu logis dan legal law (hukum formal) memberikan jalan untuk keduanya dimana logis (masuk akal) disejajarkan dengan qiyas (analogi) dimana menunjukkan minim logisnya mendapatkan pengembaliandengan jumlah besar dalam waktu singkat atau dalam usul fiqh diistilahkan dengan qiyas ma'a al-fariq (analogi pincang). Begitupun dengan eksistensi legal law (hukum formal) yang bersumber dari pemerintah supaya masyarakat selalu mempertimbangkan legalitasnya selain logisnya atau dalam istilah usul fiqh yang ditunjukkan perlunya melakukan 'indimaj antara hukum Islam dan hukum formal atau hukm wad'i. ${ }^{58}$

3. Syarat ketiga adalah maslahat yang berskala umum namun tidak bertentangan dengan spirit syariat. Pada hakikatnya, berbagai hukum yang ditetapkan dalam nas dan ijma' semuanya berorientasi maslahat dan bukan ilusi yang hanya memperdaya, mengakali dan mempengaruhi hawa nafsu sehingga mashalat ilusi tidak dibenarkan selama masih ada maslahat hakiki. Investasi dengan skema ponzi, piramida dan money game adalah maslahat ilusi yang secara jelas hanya memperdaya jajaran downline dengan iming-iming bonus tanpa kinerja keras dan kinerja cerdas..$^{59}$

Dalam realitasnya, maslahat ilusi (angan-angan, palsu) dengan iming-iming bonus yang tidak logis dianggap paradoks dengan maslahat hakiki dalam spirit ajaran Islam yang memprioritaskan urgensi literasi digital dan finansial. Mengacu pada keterkaitan corak penalaran istișlăhi dalam mitigasi resiko investasi bodong yang marak menimpa berbagai kalangan masyarakat dan selanjutnya diracik dengan menggunakan maslahah mursalah dan nalar żarīah maka terungkaplah bahwa investasi bodong hanya menjanjikan maslahat ilusi.

Dengan penggunaan nalar żarỉah yang berkaitan dengan investasi bodong tesebut maka peran Otoritas Jasa Keuangan sebagai institusi yang berperan mengatur, mengawasi dan melindungi masyarakat dinilai efektif melakukan terobosan dengan menghentikan investasi yang dicurigai melanggar aturan. Kegiatan tanpa izin usaha berpotensi menimbulkan kerugian di masyarakat dan berbahaya karena memanfaatkan ketidakpahaman masyarakat untuk menipu dengan caraimingiming pemberian imbal hasil yang sangat tinggi dan tidak wajar. ${ }^{60}$

Berdasarkan ketiga syarat yang berkenaan dengan nalar istiṣlāh tersebut maka juris Islam atau akademisi muslim yang tidak menerima penalaran filosofis tersebut dinilai menyembunyikan kemudahan dalam mengungkap maksud syar'i. Penalaran istișlāhi yang dirumuskan dalam khazanah hukum Islam adalah upaya terstruktur, sistematis dan masif dalam mengeskplorasi hukum yang bertumpu pada prinsip-prinsip kemaslahatan yang disimpulkan dalam Alquran dan hadis Rasulullah SAW.

Prinsip kemaslahatan dalam praktiknya tidak dapat dikembalikan kepada suatu ayat atau hadis secara langsung namun dalam kinerjanya menunjukkan progresivitas (kemajuan dalam

\footnotetext{
58 Hosen, "Menggagas Ijtihad Kontemporer Di Bumi Nusantara."

59 Penjelasan mengenai pentingnya memprioritaskan konsep maslahat dalam menyikapi perubahan dan menuntun kecerdasan dalam memilah antara maslahat hakiki dan ilusi. Lihat, Muhammad al Wakiliy, Fighu al Awlawiyyat Dirasah fi al Dawabit (Beirut: Ma'had Alamiy li al Fikri al Islamiy 1416 H), 133.

60 Santoso, "Fintech Ilegal Dan Investasi Bodong."
} 
pergerakannya) dengan menempuh penalaran filosofis yang berkaitan dengan konsep maqasid alsyari'ah yang dikembangkan al Syatibi. ${ }^{61}$ Metode kedua dalam penalaran istiṣlāhi setelah maslahah mursalah adalah al żarỉah yang berarti wasilah, ${ }^{62}$ namun dalam rumusannya berarti jalan yang menyampaikan atau membawa kepada keharusan dan kehalalan atau pelarangan.

Kalangan fuqaha mendikotomi nalar żarỉah antara yaitu fathu al-żarỉah dan sadd al-żarïah. Fathu al-żari'ah adalah transparansi akses yang dapat membawa kepada kemaslahatan sementara sadd alżari’ah berarti sebaliknya, yaitu menutup atau menghalangi jalan atau akses yang dinilai berpotensi ke arah keburukan. ${ }^{63}$ Nalar żarī'ah dilegitimasi beberapa ayat Alquran dan hadis Rasulullah saw. seperti dalam Surah al Baqarah ayat 104:

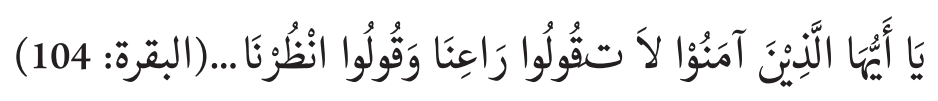

Haiorang-orangyang beriman, janganlah kamu katakan (kepada Muhammad) "Ra'ina”, tapi katakaanlah: "Unzurna" dan "dengarkanlah..."

Dalam ayat tersebut Allah SWT melarang orang-orang beriman untuk mengatakan lafal رَارعنَ meskipun dengan maksud yang baik sebagai upaya preventif menyerupai kalangan orang

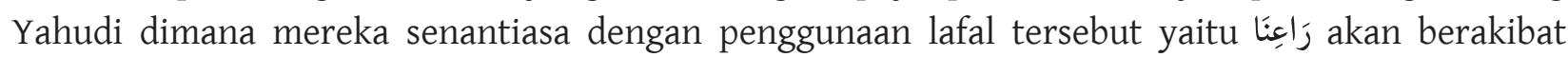
pada memperolok-olok Rasulullah SAW. ${ }^{64}$ Pelarangan tersebut menjadi upaya tidak memancing orang beriman berpenampilan sama dengan non muslim apalagi penggunaan lafal jersebut berpotensimenista martabat Rasulullah SAW..$^{65}$

Demikian pula adanya larangan untuk menikmati setetes minuman khamar sehingga tidak terjerumus kepada sesuatu yang dilarang sebagaimana yang disabdakan Rasulullah SAW sebagai berikut:

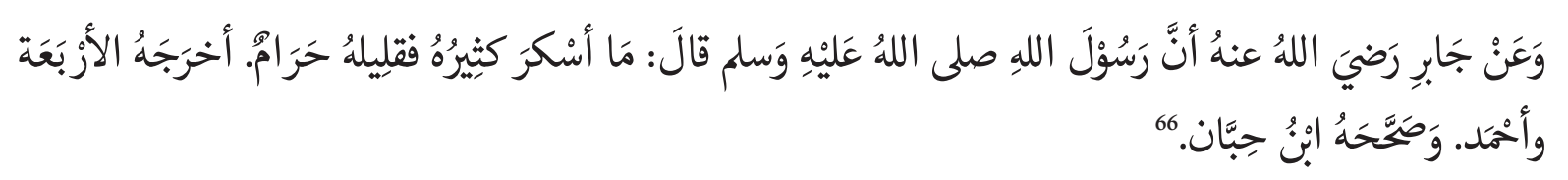

Apa saja yang memabukkan jika dikonsumsi banyak maka yang sedikitnya juga dianggap haram. Diriwayatkan oleh Imam Empat dan Ahmad. Ibn Hibban menshahihkannya. ${ }^{67}$

Aktifitas usaha investasi bodong dengan optimalisasi skema ponzi, piramida atau money game menjelma sebagai momok yang meresahkan dan merugikan peserta investasi yang ada di tingkat bawahnya sehingga pihak pemerintah atau stake holder lainnya seperti Otoritas Jasa Keuangan, Yayasan Lembaga Konsumen Indonesia, Kementerian Keuangan atau yang terkait untuk melakukan tindakan represif atau preventif baik berdasarkan laporan masyarakat atau dicurigai akan berpotensi membahayakan masyarakat, baik dengan mempidanakan atau memperdatakan, baik berdasarkan laporan atau kecurigaan sebagaimana yang diungkapkan dalam salah satu kaidah fikih:

\footnotetext{
61 Asafri Bakri Jaya, Konsep Maqasid Al Syari'ah Menurut Al Syatibi (Beirut: Dar al Qalam, 1998).

62 Khalid Ramadhan Hasan, Mu'jam Usul Al Fiqh (Bani Sawif: Dar al Tarabisyi, 2000), 146.

63 Abdu al Wahab Khallaf, Ilmu Usul Al Figh (Kairo: Dar al-Kutub al-Ilmiah, 1988), 84.

64 'Abdurrahman bin Muhammad bin Idris al Razi bin Abi Hatim, Tafsir Al Qur'an Al 'Azim Musnadan 'an Rasulillah Wa Al Sahabah Wa Al Tabi'in Mujallad Awwal (Makkah: Maktabah Nazar Mustafa al Baz, 2000), 197-8.

65 Mahmud bin Zaid al Lamisyi al Hanafi al Maturidiy, Kitab Fi Usul Al Figh (Beirut: Dar al Garb al Islamiy, 1995), $382-393$.

${ }_{66}$ Muhammad ibnu Hibban Amir 'Alauddin Ali Balban al Farisi, Sahih Ibnu Hibban (Jakarta: Pustaka Azzam, 2007).

67 Majelis Ulama Indonesia, "Fatwa Nomor 11 Tahun 2009 Tentang Hukum Alkohol” (2009).
} 
Keputusan atau kebijakan pemangku kekuasaan meminimalisir perkara.

Keputusan mengenai larangan berinvestasi dengan skema yang sarat dengan manipulasi atau penipuan telah diatur dalam keputusan pemerintah dalam bentuk UU No. 7 Tahun 2014 tentang Perdagangan yang tertera dalam pasal 105.

Undang-Undang No. 8 Tahun 1999 tentang Perlindungan Konsumen yang menjamin adanya kepastian hukum untuk konsumen dimana perlindungan konsumen berbasis manfaat, keadilan, keseimbangan, keselamatan serta kepastian hukum. ${ }^{69}$ Regulasi lainnyayang dalam hal ini memperkuat Undang-Undang tersebut seperti Peraturan POJK Nomor 1/POJK.07/2013.

Dukungan dari Ormas Islam berwujud Keputusan Munas Alim Ulama NU dalam Komisi Bahsul Masail Waqi'iyyah yang menyepakati MLM sebagai pelanggaran syariat yang terselubung yang diselenggarakan di Pondok Pesantren Miftahul Huda al Azhar, Kota Banjar, Jawa Tengah, 27 Februari 2019. Kesepakatan tersebut berbasis dari berbagai referensi seperti Kitab al-Zawajir II halaman 132, Ihya Ulumuddin Juz II halaman 76 dan beberapa kitab lainnya. Adapun Multi Level Marketing dengan mendapatkan orientasi keuntungan berdasarkan barang yang dibeli maka hukumnya diperbolehkan dan dianalogikan dengan fee.

Namun MLM dengan menggunakan konsep piramida dan downline, tidak berorientasi pada produk semata tapi dari banyaknya pengikut maka status hukumnya dilarang. Praktik semacam ini ibarat gali lobang tutup lobang. Begitupun dengan Fatwa MUI No. 4/DSN-MUI/IV/2000 tentang Murabahah. Skema yang diberlakukan adalah skema penjualan dan money game atau sejenisnya adalah kegiatan penghimpunan dana masyarakat atau penggandaan uang dengan praktik memberikan komisi dan bonus dari hasil perekrutan mitra yang baru bergabung kemudian. Artinya, bonus tadi diperoleh bukan dari hasil penjualan produk sehingga produk yang dijual hanya kamuflase belaka atau kualitasnya tidak dapat dipertanggungjawabkan bahkan tidak dibutuhkan. ${ }^{70}$

Penipuan berkedok investasi bodong kerap menggunakan sistem ponzi, piramida, MMM (Manusia Membantu Manusia) dan sejenisnya sehingga perlu penanganan secara agresif dan impulsif oleh pemerintah atau yang mewakilinya seperti Otoritas Jasa Keuangan dengan keterlibatan beberapa pemangku kepentingan seperti Yayasan Lembaga Konsumen Indonesia, Kepolisian, Kejaksaan dan Satgas Waspada Investasi yang diisi unsur Bank Indonesia, Kementerian Agama, Dinas Koperasi dan UKM, Dinas Perindustrian dan Perdagangan, Badan Penanaman Modal dan Dinas Komunikasi dan Informatika.

Pendekatan teologis normatif dan hukum (regulasi) bukan sepenuhnya instrumen yang optimal dan dipakai dalam menangani maraknya investasi yang sarat dengan manipulasi dan maslahat ilusi dan perlu pendekatan lain seperti pendekatan edukasi.Program edukasi literasi keuangan kepada publik dioptimalkan secara masif sehingga proses dan kinerja edukasi literasi keuangan terlihat progresnya dan produk atau hasil yang diharapkan sejalan dengan cita hukum yaitu kepastian, keadilan dan kemanfaatan hukum.

\footnotetext{
68 Al-Qasimiy, Al-Nizam Al-Qada’iyy Al-Islamiy (Beirut: Dar al-Kutub al-Ilmiyyah, 2011), 181.

69 Negara Republik Indonesia, “Undang-Undang No. 9 Tahun 1999 Tentang Perlindungan Konsumen” (1999).

70 Oni Sahroni, Fikih Muamalah Kontemporer (Jakarta: Republika, 2019), 123.
} 


\section{Penutup}

Teknologi dinilai sebagai instrumen untuk mewujudkan investasi yang berkualitas. Signifikansi investasi disajikan dalam skala makro atau mikro. Pengarusutamaan resiko dalam berinvestasi diwujudkan dengan pertimbangan reward menstimulus minimnya anomali hukum pidana atau perdata. Eskalasi korban dalam investasi bodong mengindikasikan literasi keuangan masyarakat masih minim dan pengarusutaman reward (iming-iming bonus) atau pengembalian dengan jumlah besar dalam waktu yang relatif singkat menjelma sebagai momok yang akan merusak tatanan ekonomi dan hukum di masayarakat. Investasi bodong yang menjamur dalam masyarakat bersejalan dengan dominasi mafsadah (keburukan dan kejahatan) yang mendegradasi kondisi ekonomi, kejiwaan, psikologi dan kepribadian bahkan maraknya tindak pidana.

Corak penalaran ta'lili (analogi dan istih̆sān) dan istiṣlāhi (maṣlahah mursalah dan żarīah) diracik secara utuh dari ilmu menjadi amal, dari nalar menjadi alur (aturan yang benar). Kolektivitas pemerintah dan stake holder dinilai apik mendegradasi investasi bodong dengan aksi preventif, represif dan kuratif. Korban meraih perlindungan hukum dengan sikap adil berkelanjutan dan oknum disanksi yang sejalan dengan cita hukum. Nalar mașlaḥah dan żarỉah dalam khazanah hukum Islam berpotensi sebagai instrumen yang terintegrasi dalam regulasi untuk menjaga, mengatur, mengawasi, dan melindungi masyarakat. Penalaran istișlāhi bukan sekedar program tanpa ada proses namun wujud nyata yang dapat diterapkan seperti sosialisasi masif berupa keberlanjutan edukasi literasi keuangan secara inovatif dan penegakan hukum dengan asas kemanfaatan, keadilan dan kepastian.

\section{DAFTAR PUSTAKA}

Adhinegara, Bhima Yudistira. “Tren Milenial Dan Industri 4.0.” Yogyakarta, 2019.

Al-Qasimiy. Al-Nizam Al-Qada’iyy Al-Islamiy. Beirut: Dar al-Kutub al-Ilmiyyah, 2011.

Arif, Firman Muhammad. "Pengembangan Metode Ijtihad Istiṣlāḥi Dalam Maqasid Al Syari'ah." Ahkam: Kajian Ilmu Hukum Dan Syariah 4, no. 1 (2014).

Arya, Fahmi. "Investasi Mikro Solusi Investasi Untuk Pemula." CNBC Indonesia, 2019. cnbcindonesia. tv.

Asmawi. Dimensi-Dimensi Syari'ah Dari Teologi, Hukum, Akhlaq Sampai Sejarah Pemikiran. Tulungagung: IAIN Tulungagung Press, 2013.

Aziz, Abdul. Manajemen Investasi Syariah. Bandung: Alfa Beta, 2010.

Barahimi, Abdul Hamid. Al 'Adalah Al Ijtimaiyyah Wa Al Tanmiyah Fi Al Iqtisad Al Islamiy. Beirut: Dar al Fikr al Mu'asir, 1997.

Djazuli, A. Kaidah-Kaidah Fikih, Kaidah-Kaidah Hukum Islam Dalam Menyelesaikan Masalah-Masalah Yang Praktis. Jakarta: Kencana Prenada Media, 2010.

Dutton, Yusuf. Asal Mula Hukum Islam, Al Qur'an, Muwatta Dan Praktik Madinah. Jakarta: Islamika, 2013.

Editorial. "Pembangunan Daerah Tertinggal Dan Transmigrasi Republik Indonesia." Kementerian Desa, 2019. kemendesa.go.id .

Farisi, Muhammad ibnu Hibban Amir 'Alauddin Ali Balban al. Sahih Ibnu Hibban. Jakarta: Pustaka Azzam, 2007. 
Fathurahman. "Pengembangan Metode Ijtihad Kontemporer." Diskursus Islam 2, no. 2 (2014).

H. Kastulani, Muhammad. \& Muhammad Suryani. "Pengaruh Investasi Dalam Pengembangan Masyarakat Lokal." Kutubkhanah 3, no. 2 (2019).

Hadi, Dwi Cahyono. \& Gayung Kasuma. “Propaganda Orde Baru 1966-1980.” Verleden 1, no. 1 (2012).

Hafid, Abu al Walid Muhammad bin Rusyd al. Al Daruriy Fi Usul Al Figh Aw Mukhtasar Al Mustasfa. Beirut: Dar al Garb al Islamiy, 1994.

Hakim, Abdul. "Perbandingan Perekonomian Dari Masa Soekarno Hingga Susilo Bambang Yudhoyono 1945-2009." Ekonomika Bisnis 3, no. 2 (2012).

Hamli. "Kebijakan Dan Strategi Pencegahan Terorisme Bersama Perguruan Tinggi Sebagai Direktur Pencegahan BNPT." In Dialog Pelibatan Civitas Academica Dalam Pencegahan Terorisme Melalui Forum Koordinasi Pencegahan Terorisme (FKPT) Sulawesi Selatan. Palopo: IAIN Palopo, 2019.

Hasan, Khalid Ramadhan. Mu’jam Usul Al Fiqh. Bani Sawif: Dar al Tarabisyi, 2000.

Hasibuan, Batara Mulia. "Investasi Dan Sejarah Perkembangan Investasi Asing Di Indonesia.” BINUS, 2019. business-law.binus.ac.id.

Hatim, 'Abdurrahman bin Muhammad bin Idris al Razi bin Abi. Tafsir Al Qur'an Al 'Azim Musnadan 'an Rasulillah Wa Al Sahabah Wa Al Tabi'in Mujallad Awwal. Makkah: Maktabah Nazar Mustafa al Baz, 2000.

Hayati, Mardhiyah. "Investasi Menurut Perspektif Ekonomi Islam.” Ikonomika: Jurnal Ekonomi Dan Bisnis Islam 1, no. 1 (2016).

Hosen, Nadirsyah. "Menggagas Ijtihad Kontemporer Di Bumi Nusantara." In Milad Ke-50 IAIN Tulungagung. IAIN Tulungagung: IAIN Tulungagung Press, 2018.

Hutapea, Hotman Paris. \& Ajeng Kamaratih. “Investasi Bodong Dan Perlindungan Perempuan.” Metro TV. Indonesia, 2019.

Idrus, Ahmad Musyahid. "Tradisi Penalaran Filosofis Dalam Hukum Islam.” Al Daulah 3, no. 1 (2014).

Indrawati, Sri Mulyani. "Perkembangan Investasi Di Indonesia Tahun 2019." Sahabat Pegadaian, 2018. sahabatpegadaian.com.

Ismatullah, Dedi. Sejarah Sosial Hukum Islam. Bandung: Pusataka Setia, 2011.

Jalil, Abdul. “Sepak Terjang Bos Q-Net Asal Madiun Terhenti Di Lumajang.” Suara Bisnis, 2019.

Jaya, Asafri Bakri. Konsep Maqasid Al Syari'ah Menurut Al Syatibi. Beirut: Dar al Qalam, 1998.

Khallaf, Abdu al Wahab. Ilmu Usul Al Figh. Kairo: Dar al-Kutub al-Ilmiah, 1988.

Khallaf, Abdul Wahab. Masadir Al Tayri' Al Islamiy Ma La Nas Fih. Kuwait: Dar al Qalam li Nasyri wa al Tawzi', 1992.

Kholis, Nur. “Antisipasi Hukum Islam Dalam Menjawab Problematika Kontemporer: Kajian Terhadap Pemikiran Maslahah Mursalah Al Ghazali.” Al Mawarid 1, no. 1 (2010).

Kuntowijoyo. Pengantar Ilmu Sejarah. Yogyakarta: Bentang Budaya, 1995.

Majelis Ulama Indonesia. Fatwa Nomor 11 Tahun 2009 Tentang Hukum Alkohol (2009).

Maturidiy, Mahmud bin Zaid al Lamisyi al Hanafi al. Kitab Fi Usul Al Fiqh. Beirut: Dar al Garb al Islamiy, 1995. 
Negara Republik Indonesia. Undang-Undang No. 9 Tahun 1999 Tentang Perlindungan Konsumen (1999).

Nurdin, Zainal Ibnu. "Peran Investasi Asing Dalam Perekonomian Indonesia Tahun 1967-1998." repository.upi.edu, 2019.

Poesoro, AwanWibowoLaksono."MembangkitkanInvestasiDiIndonesia,"2019.theindonesiainstitute. com.

Rizqan, Latif. “Investasi Dalam Islam Dan Penerapannya.” Kompasiana, 2019. kompasiana.com.

Rokhmatussa'dyah, Ana \& Suratman. Hukum Investasi \& Pasar Modal. Jakarta: Sinar Grafika, 2011.

Sahroni, Oni. Fikih Muamalah Kontemporer. Jakarta: Republika, 2019.

Sakinah. "Investasi Dalam Islam.” Iqtishadia 1, no. 2 (2014).

Salih, Fawzi Usman. Al Qawa'id Wa Al Dawabit Al Fighiyyah Wa Tatbiqatuha Fi Al Siyasah Al Syar'iyyah. Riyadh: Dar al 'Asimah, 2011.

Santoso, Wimboh \& Tongan Lumban Tobing. “Fintech Ilegal Dan Investasi Bodong.” In Kuliah Umum Bersama Otoritas Jasa Keuangan \& Satgas Waspada Investasi. Jember: Fakultas Ekonomi dan Bisnis Universitas Jember, 2019.

Setu, Ferdinandus. "Fintech Ilegal Tidak Pernah Mati.” Berita Satu TV. Jakarta, 2019.

Sugiarto, Eddy Cahyono. “Investasi Dan Indonesia Maju.” Kementerian Sekretariat Negara Republik Indonesia, 2019. setneg.go.id.

Sugiyanto, Danang. “Investasi Asing Mengalir Ke RI Sejak Era Orde Baru.” Detik, 2018. finance.detik. com.

Syalabi, Muhammad Mustafa. Ta’lil Al Ahkam. Beirut: Dar al Nahdah al ‘Arabiyyah, 1981.

Tobing, Tongam Lumban. “Jangan Tertipu, Ini Daftar Invstasi Bodong Yang Ditutup OJK." CNBC Indonesia, 2019. cnbcindonesia.com.

-_- "Perang Melawan Investasi Ilegal." Edukasi Konsumen. Jakarta, 2017.

Yoga, Paulus. "Asuransi Kesehatan, Tabungan Atau Investasi." Infobanknews, 2017. infobanknews. com.

Zaki, Muhammad. “Aplikasi Maqasid Al Syari’ah Pada Sistem Keuangan Syariah.” BISNIS 3, no. 2 (2015).

Zulfahri, Yudi. “Testimoni Mantan Anggota Jaringan Terorisme.” In Dialog Pelibatan Civitas Academica Dalam Pencegahan Terorisme Melalui Forum Koordinasi Pencegahan Terorisme (FKPT) Sulawesi Selatan. Palopo: IAIN Palopo Press, 2019. 